\title{
Development of an Amorphous Silica from Rice Husk Waste
}

\author{
Daddan Khan Bangwar \\ Department of Civil Engineering \\ Quaid-e-Awam University of \\ Engineering, Science \& Technology \\ Nawabshah, Sindh, Pakistan \\ daddan@quest.edu.pk
}

Mukhtiar Ali Soomro

Department of Civil Engineering

Quaid-e-Awam University of Engineering,

Science \& Technology

Nawabshah, Pakistan

eng.soomro@gmail.com

\author{
Abdullah Saand \\ Quaid-e-Awam University of \\ Engineering, Science \& Technology \\ Nawabshah, Sindh, Pakistan \\ abdullah@quest.edu.pk
}

\author{
Manthar Ali Keerio \\ Quaid-e-Awam University of \\ Engineering, Science \& Technology \\ Nawabshah, Sindh, Pakistan \\ mantharali99@quest.edu.pk
}

\begin{abstract}
This article presents a study on the development of amorphous silica from Rice Husk (RH) waste. For ascertaining the optimum proportion of temperature and burning duration required for the development of an amorphous silica from $\mathrm{RH}$ waste, different Rice Husk Ash (RHA) samples, i.e. RHA $\left(500^{\circ} \mathrm{C}\right.$ $1.5 \mathrm{hr})$, RHA $\left(500^{\circ} \mathrm{C}-2 \mathrm{hr}\right)$, RHA $\left(600^{\circ} \mathrm{C}-1.5 \mathrm{hr}\right)$, RHA $\left(600^{\circ} \mathrm{C}-2 \mathrm{hr}\right)$, RHA $\left(700^{\circ} \mathrm{C}-1.5 \mathrm{hr}\right)$, RHA $\left(700^{\circ} \mathrm{C}-2 \mathrm{hr}\right)$, RHA $\left(800^{\circ} \mathrm{C}-1.5 \mathrm{hr}\right)$, RHA $\left(800^{\circ} \mathrm{C}-2\right)$ and $\mathrm{RHA}\left(900^{\circ} \mathrm{C}-1 \mathrm{hr}\right)$ were extracted by burning the husk at different temperatures and durations. Energy Dispersive Spectrometry (EDS) analysis was carried out for ascertaining the existence of main and insignificant elements in the RHAs samples and it was noticed that the extracting of silicon dioxide $\left(\mathrm{SiO}_{2}\right)$ was exclusively dependent on the temperature and burning duration. After EDS, X-ray Diffraction (XRD) analysis was used to find out the crystalline and non-crystalline nature of obtained silica at different temperatures and burning durations. Through EDS and XRD, it has been found that that the extracted Rice Husk Ash at the temperature of $800^{\circ} \mathrm{C}$ for $2 \mathrm{hr}$ is rich in amorphous $\mathrm{SiO}_{2}$ content, i.e. 91.74\% which meets the requirements of ASTM 61803 for a pozzolanic material.
\end{abstract}

Keywords-amorphous silica; strength activity index; XRD; RHA; cement replacement

\section{INTRODUCTION}

Rice husk is an agrarian by-product substance that constitutes at around $20 \%$ weight of rice. It is composed of $80 \%$ organic volatile material and $20 \%$ silica [1]. Rice husk ash is a wide-ranging term describing all kinds of ash formed from burning rice husk. Silica ash is produced upon burning and subsequently cellulose and lignin are removed. Every ton of rice generates $40 \mathrm{~kg}$ of ash [2]. RHA is a very fine pozzolanic material and is an extremely reactive pozzolanic material to be obtained upon the calcination of rice husk under the crystallization temperature at $780^{\circ} \mathrm{C}[3,4]$. In practice, the sort

\author{
Nadeem-ul-Karim Bhatti \\ Department of Civil Engineering \\ Quaid-e-Awam University College of Engineering, Science \\ and Technology \\ Larkano, Pakistan \\ knadeem_b@yahoo.com
}

of ash differs significantly according to the burning method. The ash manufactured by controlled burning of the rice husk between $550^{\circ} \mathrm{C}$ and $700^{\circ} \mathrm{C}$ burning temperature for 1 hour converts the silica content of the ash into amorphous phase [5, 6]. The silica in the ash undergoes structural changes depending on the temperature, at $550-800^{\circ} \mathrm{C}$ amorphous silica is formed and at greater temperatures, crystalline silica is formed. Rice husk ash modified concrete is exceptional in terms of strength and durability performance [7-9]. Usually after the extraction, the produced RHA is ground by using abrasion machines, however, the researchers in [2] stated that non-ground rice husk ash could be used to substitute $15 \%$ of Portland cement with similar mechanical and durability properties. The researchers in $[10,11]$ showed that by blending RHA as cement replacement material in concrete, the wideranging enhancements in durability properties that can be achieved are otherwise difficult to attain by use of ordinary cement only. The main focus of this research is to develop supplementary cementing material from locally available waste material Rice Husk, and to mitigate the ecological contamination initiated by the rice husk as well as cement production.

\section{EXPERIMENTIAL PROCEDURE}

\section{A. Rice Husk Ash Sample Preparation}

Rice husk was collected from Nawabshah district, Sind, Pakistan. The husk was cleaned thoroughly by picking unwanted substances like stone, debris etc. Nine samples of rice husk ash were extracted with the help of a muffle furnace having temperature ranged up to $1000^{\circ} \mathrm{C}$ and these samples were categorized as $\operatorname{RHA}\left(500^{\circ} \mathrm{C}-1.5 \mathrm{hr}\right), \operatorname{RHA}\left(500^{\circ} \mathrm{C}-2 \mathrm{hr}\right)$, RHA $\left(600^{\circ} \mathrm{C}-1.5 \mathrm{hr}\right), \quad \operatorname{RHA}\left(600^{\circ} \mathrm{C}-2 \mathrm{hr}\right), \quad \operatorname{RHA}\left(700^{\circ} \mathrm{C}-1.5 \mathrm{hr}\right)$, $\operatorname{RHA}\left(700^{\circ} \mathrm{C}-2 \mathrm{hr}\right), \operatorname{RHA}\left(800^{\circ} \mathrm{C}-1.5 \mathrm{hr}\right), \operatorname{RHA}\left(800^{\circ} \mathrm{C}-2 \mathrm{hr}\right)$ and 
RHA $\left(900^{\circ} \mathrm{C}-1 \mathrm{hr}\right)$. All samples were burnt under the temperature scheme for one and a half or two hours, respectively except the sample RHA $\left(900^{\circ} \mathrm{C}-1 \mathrm{hr}\right)$ which was extracted under the duration of one hour only.

\section{B. Chemical Analysis of Rice Husk Ash}

Elemental composition of all extracted Rice husk ash samples, i.e. $\operatorname{RHA}\left(500^{\circ} \mathrm{C}-1.5 \mathrm{hr}\right), \quad \operatorname{RHA}\left(500^{\circ} \mathrm{C}-2 \mathrm{hr}\right)$, $\operatorname{RHA}\left(600^{\circ} \mathrm{C}-1.5 \mathrm{hr}\right), \quad \operatorname{RHA}\left(600^{\circ} \mathrm{C}-2 \mathrm{hr}\right), \quad \operatorname{RHA}\left(700^{\circ} \mathrm{C}-1.5 \mathrm{hr}\right)$, $\operatorname{RHA}\left(700^{\circ} \mathrm{C}-2 \mathrm{hr}\right), \operatorname{RHA}\left(800^{\circ} \mathrm{C}-1.5 \mathrm{hr}\right), \operatorname{RHA}\left(800^{\circ} \mathrm{C}-2 \mathrm{hr}\right)$ and RHA $\left(900^{\circ} \mathrm{C}-1 \mathrm{hr}\right.$ ) was determined through (X-ray Energy Dispersive Spectrometry) EDS test by applying energy of 15 $\mathrm{KeV}$ accelerating voltages to ensure the peaks record.

\section{Loss on Ignition}

To determine the amount of carbon in produced Rice husk ash (RHA), the loss on ignition was determined by keeping the samples in Muffle Furnace at a temperature of $950^{\circ} \mathrm{C}$ for 45 minutes.

\section{Crystalline and Non-crystalline nature of Rice Hush Ash}

The amount of amorphous silica present in the material is an important factor in determining how effective it will be as a pozzolan. Studies have shown that the greater the amount of amorphous, the better pozzolanic reactivity a material will have when combined with water. The "degree of amorphous" can be measured using X-Ray Diffraction (XRD) which was used in this study. The crystalline and non-crystalline characteristics of the samples were determined qualitatively by X-ray diffraction (XRD). The diffractograms were obtained using $\mathrm{Cu}$ monochromator for ground sample over a $10-73^{\circ} \mathrm{C}$ at $2 \theta$ range.

\section{E. Fineness}

Fineness is the ratio of surface area to weight which is deemed to be a significant quality index of a pozzolanic material that gives the average size of grain of a material. Fineness controls the rate and completeness of hydration. The Blaine specific area of the RHA $\left(800^{\circ} \mathrm{C}-2 \mathrm{hr}\right)$ is determined as per ASTM C204.

\section{F. Specific Gravity}

The specific gravity of RHA $\left(800^{\circ} \mathrm{C}-2 \mathrm{hr}\right)$ was calculated with the help of Density Bottle Method. Each sample of RHA $\left(800^{\circ} \mathrm{C}-2 \mathrm{hr}\right)$ was dried in oven at $110^{\circ} \mathrm{C}$ to remove any moisture.

\section{G. Density}

The average density of the extracted RHA $\left(800^{\circ} \mathrm{C}-2 \mathrm{hr}\right)$ has been determined as per ASTM standards.

\section{H. Strength Activity Index}

Mortar specimens were cast by $20 \%$ replacement of cement with extracted rice husk ash RHA $\left(800^{\circ} \mathrm{C}-2 \mathrm{hr}\right)$ by weight. The mortar mixes were designed by using a Sand-to-Binder ratio (S/B) of 2.75 and W/B of 0.49 , as per ASTM C 311 . The mix details are given in Table I. Mixing, compaction and molding have been carried out in accordance with ASTM C305 [12] and
ASTM C109 [13] respectively. The specimens were cast and taken out of the molds after 24 hours and kept in a totally wet environment for 7 and 28 days for curing and Strength Activity Index (SAI) was calculated.

TABLE I. MIX PROPORTION OF MORTAR

\begin{tabular}{|c|c|c|c|c|}
\hline $\operatorname{Mix}(\mathbf{I D})$ & $\begin{array}{c}\text { Cement } \\
\mathbf{( g m})\end{array}$ & $\begin{array}{c}\text { RHA } \\
\left(\mathbf{8 0 0}^{\mathbf{0}} \mathbf{C}-\mathbf{2 h r}\right)\end{array}$ & $\begin{array}{c}\text { W/B } \\
(\mathbf{r a t i o})\end{array}$ & $\begin{array}{c}\text { Sand } \\
\mathbf{( g m})\end{array}$ \\
\hline $\mathrm{A}$ & 1000 & --- & 0.49 & 2750 \\
\hline $\mathrm{B}$ & 800 & 200 & 0.49 & 2750 \\
\hline
\end{tabular}

\section{RESULTS AND DISCUSSION}

\section{A. Chemical Analysis Rice Husk Ash}

The Energy Dispersive Spectrometry (EDS) analysis was carried out to categorize and figure out the primary and secondary elements existing in the samples of produced rice hush ash. Elemental composition of all samples is shown in Figure 1. Figure 1 shows that RHA contains a high proportion of pure silica ranging from $37.7 \%$ to $43.04 \%$, with each of other minor elements having lower percentage. Elemental compositions in percentage by weight in oxidation form are tabulated and are shown in Table II. The results in the table verify that the material is largely composed of $\mathrm{SiO}_{2}$ ranging from $80.68 \%$ to $92.11 \%$ which is solely dependent of temperature and burning duration. Such trend of the material is also validated by [14]. Additionally, a comparison is made between the EDS results of the samples. It can be seen that there is an increasing trend in the quantity of silicon dioxide content with the increase of temperature and burning duration. The results in Table II also validate that the extracting of silica purely depends upon the temperature and burning duration. Furthermore, the sum of major elements like $\mathrm{SiO}_{2}+\mathrm{Al}_{2} \mathrm{O}_{3}+\mathrm{Fe}_{2} \mathrm{O}_{3}$ in all samples is above $70 \%$. All the extracted samples conform to the requirement of ASTM C61803.

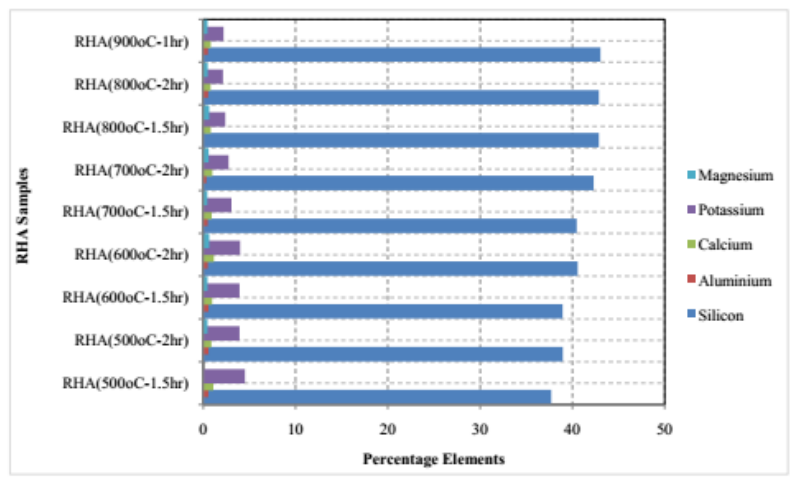

Fig. 1. Elemental composition of RHAs sample

\section{B. Loss on Ignition of Rice Husk Ash}

The loss on ignition for rice husk ash is usually due to the presence of unburned carbon (indicating the burning efficiency of the furnace). Burning the husk at high temperature causes instability of the mineral phases [15]. Figure 2 shows the 
relationship between loss on ignition (LOI) and extraction of $\mathrm{SiO}_{2}$ of all samples. LOI went on decreasing as the temperature and its duration kept on increasing resulting in more extraction of silica content. The increased LOI suggests that an increased quantity of less burnt carbon content in RHAs has adverse effects when blended with cement. In order to achieve better results rice husk ash blended concrete or mortar in terms of strength and durability, the ash must have less LOI as per requirement of ASTM.

TABLE II. CHEMICAL ANALYSIS OF RHA AT DIFFERENT TEMPERATURE AND DURATION

\begin{tabular}{|c|c|c|c|c|c|c|}
\hline \multirow{2}{*}{ Samples } & \multicolumn{6}{|c|}{ Chemical Analysis (\%) } \\
\hline & $\mathrm{SiO}_{2}$ & $\mathrm{Al}_{2} \mathrm{O}_{3}$ & $\mathrm{CaO}$ & $\mathrm{MgO}$ & $\mathrm{K}_{2} \mathrm{O}$ & $L O I$ \\
\hline $\operatorname{RHA}\left(500^{\circ} \mathrm{C}-1.5 \mathrm{hr}\right)$ & 80.68 & 1.04 & 1.51 & 0.78 & 4.60 & 6.00 \\
\hline RHA $\left(500^{\circ} \mathrm{C}-2 \mathrm{hr}\right)$ & 83.37 & 1.06 & 1.22 & 0.75 & 4.02 & 5.00 \\
\hline $\operatorname{RHA}\left(600^{\circ} \mathrm{C}-1.5 \mathrm{hr}\right)$ & 83.33 & 1.08 & 1.34 & 0.78 & 4.02 & 4.00 \\
\hline $\operatorname{RHA}\left(600^{\circ} \mathrm{C}-2 \mathrm{hr}\right)$ & 86.80 & 0.91 & 1.61 & 1.06 & 4.08 & 3.67 \\
\hline $\operatorname{RHA}\left(700^{\circ} \mathrm{C}-1.5 \mathrm{hr}\right)$ & 86.58 & 0.91 & 1.27 & 0.73 & 3.11 & 3.00 \\
\hline RHA $\left(700^{\circ} \mathrm{C}-2 \mathrm{hr}\right)$ & 90.52 & 1.02 & 1.39 & 0.98 & 2.79 & 2.45 \\
\hline $\operatorname{RHA}\left(800^{\circ} \mathrm{C}-1.5 \mathrm{hr}\right)$ & 91.72 & 0.98 & 1.15 & 1.06 & 2.43 & 2.00 \\
\hline $\mathrm{RHA}\left(800^{\circ} \mathrm{C}-2 \mathrm{hr}\right)$ & 91.74 & 0.98 & 1.12 & 0.81 & 2.18 & 1.50 \\
\hline $\operatorname{RHA}\left(900^{\circ} \mathrm{C}-1 \mathrm{hr}\right)$ & 92.11 & 2.00 & 1.15 & 0.76 & 2.23 & 1.00 \\
\hline
\end{tabular}

\section{Crystalline and Non-crystalline Nature of Rice Hush Ash}

After combustion, XRD analysis was carried out to assess presence of crystalline and amorphous substances in all samples. The XRD patterns of the RHAs at different temperatures and durations are presented in Figures 3 to 11 . The results in Figures 3 - 10 show that the XRDs patterns of $\operatorname{RHA}\left(500^{\circ} \mathrm{C}-1.5 \mathrm{hr}\right), \quad \operatorname{RHA}\left(500^{\circ} \mathrm{C}-2 \mathrm{hr}\right), \quad \operatorname{RHA}\left(600^{\circ} \mathrm{C}-1.5 \mathrm{hr}\right)$, $\operatorname{RHA}\left(600^{\circ} \mathrm{C}-2 \mathrm{hr}\right), \quad \operatorname{RHA}\left(700^{\circ} \mathrm{C}-1.5 \mathrm{hr}\right), \quad \operatorname{RHA}\left(700^{\circ} \mathrm{C}-2 \mathrm{hr}\right)$, $\operatorname{RHA}\left(800^{\circ} \mathrm{C}-1.5 \mathrm{hr}\right)$ and $\mathrm{RHA}\left(800^{\circ} \mathrm{C}-2 \mathrm{hr}\right)$ having broad peak at $2 \theta$ angle of $19^{\circ}$ confirming the material contain an amorphous silica structure. Conversely, the XRD of RHA $\left(900^{\circ} \mathrm{C}-1 \mathrm{hr}\right)$ shows sharp peaks at around $2 \theta$ angle of $19^{\circ}$ and $33^{\circ}$ which clearly indicates converting of the nature of the silica from amorphous to crystalline nature because of increased temperature (Figure 11). It means that reactivity of rice husk ash is generally decreased by the increasing of burning temperature and the heating duration. Furthermore, a comparison is made between the XRD patterns of RHAs as shown in Figure 12 which is clearly indicating the conversion of silicon dioxide from an amorphous state to crystalline state, i.e. the development of sharp peaks at around $19^{\circ}$ and $33^{\circ}$ due to the increased temperature.

The extracted silica must be kept at a non-crystalline state in order to produce an ash with high pozzolanic activity. The optimum temperature range for RHA has not been in common agreement, since it has reported to be 600 to $800^{\circ} \mathrm{C}$ [16], 500 to $700^{\circ} \mathrm{C}$ [17] and 700 to $800^{\circ} \mathrm{C}$ [18]. From the current research study it is clear that the combination of $800^{\circ} \mathrm{C}$ temperature for 2 hour burning time seems to present the optimized solution resulting in non-crystallized RHA. Such type of noncrystallized RHA is a suitable supplementary cementing material, since high pozzolanic activity is necessary for it is to substitute cement or be admixtured in concrete.

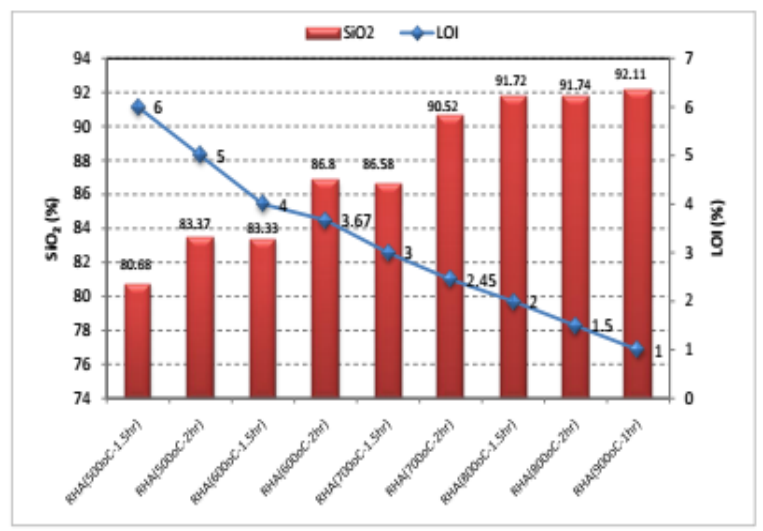

Fig. 2. Extraction of silica di-oxide under various temperatures and durations

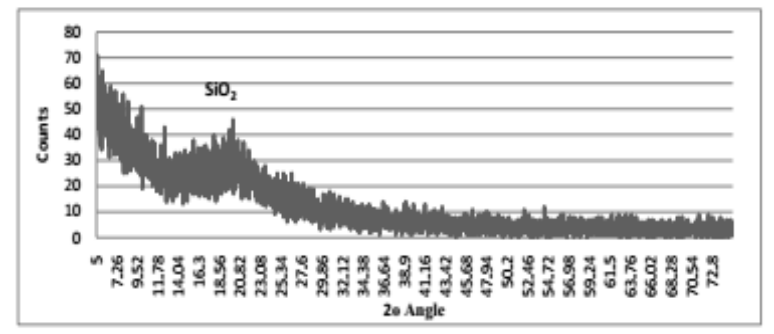

Fig. 3. XRD pattern of RHA $\left(500^{\circ} \mathrm{C}-1.5 \mathrm{hr}\right)$

\section{Blaine Fineness}

Specific surface area of the optimized RHA $\left(800^{\circ} \mathrm{C}-2 \mathrm{hr}\right)$ is shown in Table III. The results suggest that it is slightly coarser than ordinary Portland cement. From fineness test, the fineness of the RHA $\left(800^{\circ} \mathrm{C}-2 \mathrm{hr}\right)$ as retained on $45 \mu \mathrm{m}$ was found $20 \%$ and $80 \%$ passing, which is within the limits defined by ASTM C618-03 and the ash conformed to grade A of dry pulverizedfuel ash based on ASTM C430 [19].

\section{E. Specific Gravity}

Specific gravity of the optimized RHA $\left(800^{\circ} \mathrm{C}-2 \mathrm{hr}\right)$ is shown in Table III. The results show that the material is lighter in nature than the cement. The found specific gravity falls within the range of the values seen in the work carried out by other researchers [20,21].

\section{F. Strength Activity Index}

Strength Activity Index (SAI) demonstrates a greater pozzolanic activity index of the optimized RHA $\left(800^{\circ} \mathrm{C}-2 \mathrm{hr}\right)$. SAI at 7-days and 28 -days was $88 \%$ and $92 \%$, respectively. The SAI results clearly indicate that RHA $\left(800^{\circ} \mathrm{C}-2 \mathrm{hr}\right)$ is in amorphous state and reactive in nature. Furthermore, the strength gaining percentage is above the standards demarcated by the ASTM C 618-03 as shown in Table III. Such strength gaining pattern is validated by $[22,23]$. 


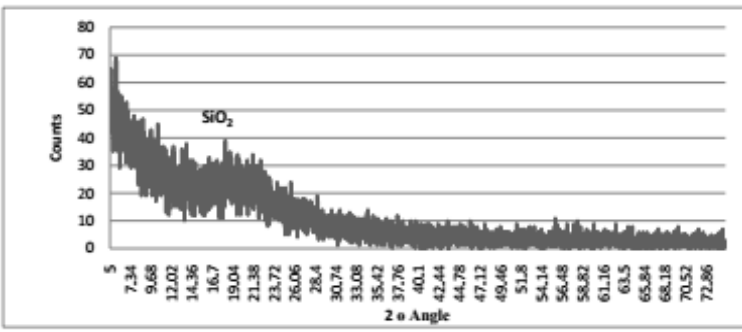

Fig. 4. XRD pattern of RHA $\left(500^{\circ} \mathrm{C}-2 \mathrm{hr}\right)$

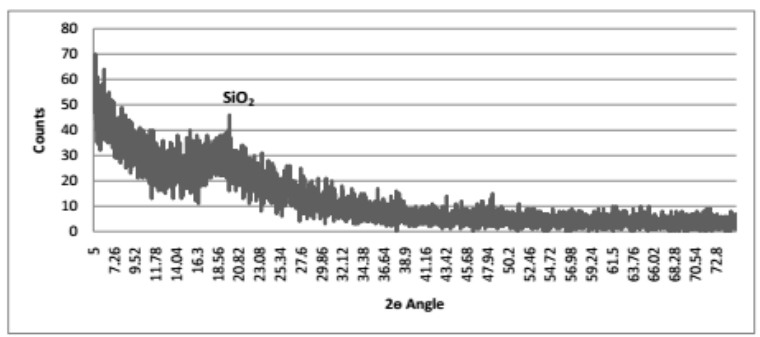

Fig. 5. XRD pattern of RHA $\left(600^{\circ} \mathrm{C}-1.5 \mathrm{hr}\right)$

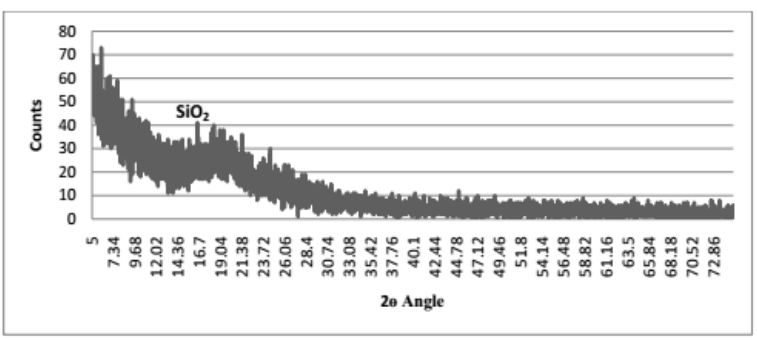

Fig. 6. XRD pattern of RHA $\left(600^{\circ} \mathrm{C}-2 \mathrm{hr}\right)$

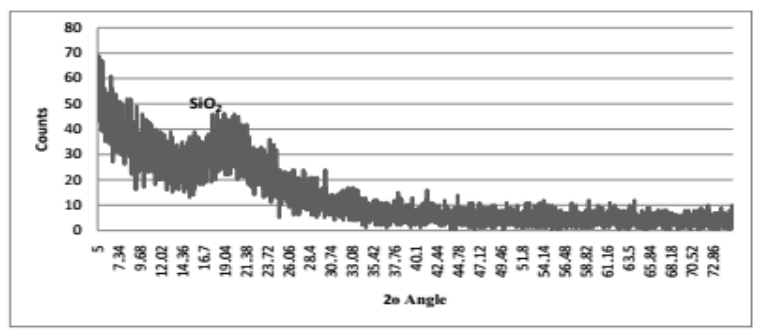

Fig. 7. XRD pattern of RHA $\left(700^{\circ} \mathrm{C}-1.5 \mathrm{hr}\right)$

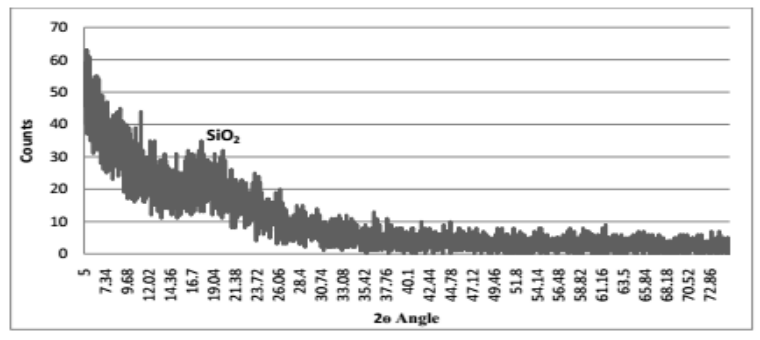

Fig. 8. XRD pattern of RHA $\left(700^{\circ} \mathrm{C}-2 \mathrm{hr}\right)$

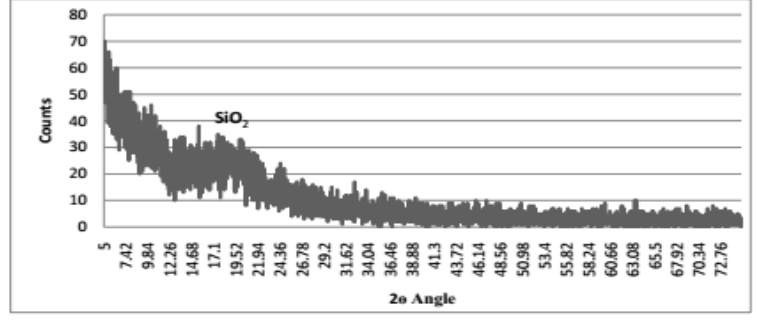

Fig. 9. XRD pattern of RHA $\left(800^{\circ} \mathrm{C}-1.5 \mathrm{hr}\right)$

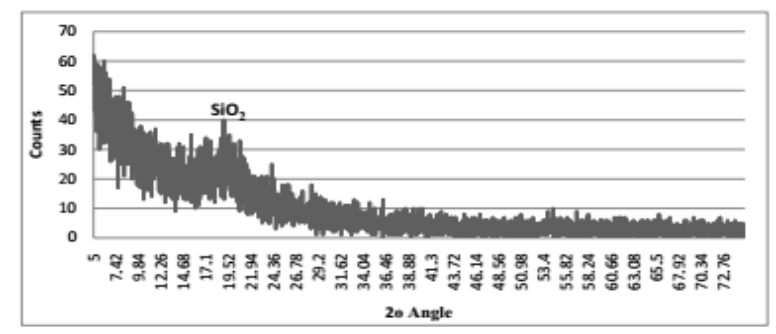

Fig. 10. XRD pattern of RHA $(800 \mathrm{oC}-2 \mathrm{hr})$

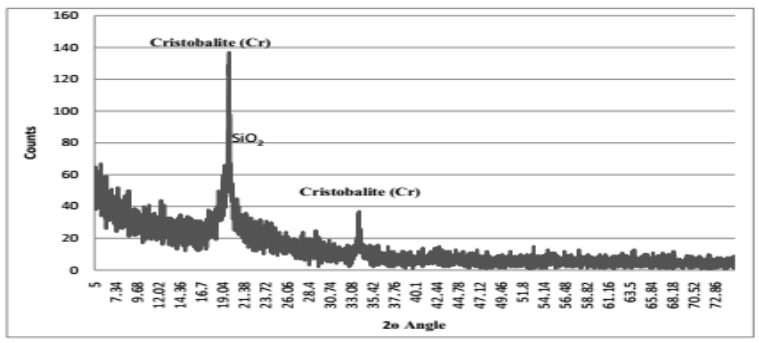

Fig. 11. XRD pattern of RHA $(900 \mathrm{oC}-1 \mathrm{hr})$

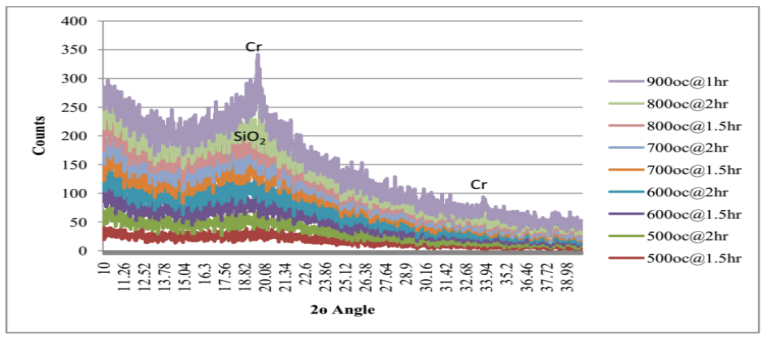

Fig. 12. Comparison of RXDs of produced RHA at different temperatures and duration

TABLE III. PHYSICAL PROPERTIES THE OPTIMIZED RHA

\begin{tabular}{|c|c|c|}
\hline Physical Properties & $\begin{array}{c}\text { ASTM } \\
\text { C-618 }\end{array}$ & $\begin{array}{c}\text { RHA } \\
\mathbf{( 8 0 0 0 C - 2 h r )}\end{array}$ \\
\hline Blaine fineness $\left(\mathrm{cm}^{2} / \mathrm{g}\right)$ & - & 2251 \\
\hline Fineness & 34 & 20 \\
\hline Strength Activity Index (\%) & 75 & $88 \& 92$ \\
\hline Specific gravity & - & 2.05 \\
\hline
\end{tabular}




\section{CONCLUSION}

In-depth analysis of the extracted Rice Hush Ash (RHA) samples at different temperatures and durations from locally available rice husk has been investigated and found that the extracted ash at the temperature of $800^{\circ} \mathrm{C}$ for 2 hour duration is the optimum one in terms of amorphous silicon dioxide, with a percentage of $\mathrm{SiO}_{2}$ at $91.74 \%$. Thus chemical and physical properties of the extracted ash at the temperature $800^{\circ} \mathrm{C}$ for 2 hour duration fulfill the requirements of ASTM C618-03 standard as a pozzolanic material. Consequently, the developed ash can be used as a supplementary cementing material.

\section{ACKNOWLEDGEMENT}

The authors express their thanks to Civil Engineering Department QUEST Nawabshah for the support.

\section{REFERENCES}

[1] S. R. Kamath, A. Proctor, "Silica gel from rice hull ash: preparation and characterization", Cereal Chemistry, Vol. 75, pp. 484-487, 1998

2] R. Zerbino, G. Giaccio, G. C. Isaia, "Concrete incorporating rice-husk ash without processing", Construction and Building Materials, Vol. 25, No. 1, pp. 371-378, 1, 2011

[3] V. M. Malhotra, P. Kumar Mehta, Pozzolanic and cementitious materials Vol. 1, Taylor \& Francis, 1996

[4] Q. Yu, K. Sawayama, S. Sugita, M. Shoya, Y. Isojima, "The reaction between rice husk ash and $\mathrm{Ca}(\mathrm{OH}) 2$ solution and the nature of its product", Cement and Concrete Research, Vol. 29, No. 1, pp. 37-43, 1999

[5] J. James, M. S. Rao, "Silica from rice husk through thermal decomposition", Thermochimica Acta, Vol. 97, pp. 329-336, 1986

[6] A. A. Boateng, D. A. Skeete, "Incineration of rice hull for use as a cementitious material: the guyana experience", Cement and Concrete Research, Vol. 20, No. 5, pp. 795-802, 1990

[7] M. Anwar, T. Miyagawa, M. Gaweesh, "Using rice husk ash as a cement replacement material in concrete", Waste Management Series, Vol. 1, pp. $671-684,2000$

[8] J. Sousa Coutinho, "The combined benefits of CPF and RHA in improving the durability of concrete structures", Cement and Concrete Composites, Vol. 25, No. 1, pp. 51-59, 2003

[9] M. F. M. Zain, M. N. Islam, F. Mahmud, M. Jamil, "Production of rice husk ash for use in concrete as a supplementary cementitious material", Construction and Building Materials, Vol. 25, No. 2, pp. 798-805, 2011

[10] C. L. Hwang, S. Chandra, "The use of rice husk ash in concrete", in Waste Materials Used in Concrete Manufacturing, William Andrew Publishing/Noyes, Norwich, NY, pp. 184-234, 1997

[11] M. L. Gambhir, Concrete technology, Tata McGraw-Hill Education, 2004

[12] ASTM, C305, Standard practice for mechanical mixing of hydraulic cement pastes and mortars of plastic consistency, Annual book of ASTM standards, ASTM International, PA, 2006

[13] ASTM, C109/C109M-16a. Standard test method for compressive strength of hydraulic cement mortars (Using 2-in. or [50-mm] cube specimens), ASTM International, PA, 2002

[14] V. Vaibhav, U. Vijayalakshmi, S. Mohana Roopan, "Agricultural waste as a source for the production of silica nanoparticles", Spectrochimica Acta Part A: Molecular and Biomolecular Spectroscopy, Vol. 139, pp. $515-520,2015$

[15] J. de C. Izidoro, D. A. Fungaro, F. S. dos Santos, S. Wang "Characteristics of Brazilian coal fly ashes and their synthesized zeolites", Fuel Processing Technology, Vol. 97, pp. 38-44, 2012

[16] M. Rozainee, S. P. Ngo, A. A. Salema, K. G. Tan, M. Ariffin, Z. N. Zainura, "Effect of fluidising velocity on the combustion of rice husk in a bench-scale fluidised bed combustor for the production of amorphous rice husk ash”, Bioresource Technology, Vol. 99, No. 4, pp. 703-713, 2008

[17] D. G. Nair, A. Fraaij, A. A. K. Klaassen, A. P. M. Kentgens, "A structural investigation relating to the pozzolanic activity of rice husk ashes", Cement and Concrete Research, Vol. 38, No. 4, pp. 861-869, 2008

[18] S. Huang, S. Jing, J. Wang, Z. Wang, Y. Jin, "Silica white obtained from rice husk in a fluidized bed", Powder Technology, Vol. 117, No. 3, pp. 232-238, 2001

[19] ASTM, C430. Standard Test Method for Fineness of Hydraulic Cement by the 45-Mm (No. 325) Sieve, ASTM International, PA, 2003

[20] L. A. Bui, C. Chen, C. Hwang, W. Wu, "Effect of silica forms in rice husk ash on the properties of concrete", International Journal of Minerals, Metallurgy, and Materials, Vol. 19, No. 3, pp. 252-258, 2012

[21] P. K. Mehta,"Rice Husk Ash-A Unique Supplementary Cementing Material", in Advances in Concrete Technology, CANMET, 1992

[22] C. Y. Kawabata, H. Savastano Jr, J. Sousa-Coutinho, "Rice husk derived waste materials as partial cement replacement in lightweight concrete", Ciencia e Agrotecnologia, Vol. 36, No. 5, pp. 567-578, 2012

[23] R. Madandoust, R. Ghavidel, "Mechanical properties of concrete containing waste glass powder and rice husk ash", Biosystems Engineering, Vol. 116, No. 2, pp. 113-119, 2013 